\title{
PELATIHAN KORESPONDENSI UNTUK MENINGKATKAN KETERAMPILAN MENULIS SURAT PADA PENGURUS KARANG TARUNA DESA CANDIREJO KECAMATAN PONGGOK KABUPATEN BLITAR
}

\author{
Agus Hermawan ${ }^{1}$, Sri Utami2, Saptono Hadi ${ }^{3}$ \\ ${ }^{1}$ Universitas Nahdlatul Ulama Blitar. Email: agushermawan8992@gmail.com \\ 2Universitas Nahdlatul Ulama Blitar. Email:utami3215@gmail.com \\ 3Universitas Nahdlatul Ulama Blitar. Email: saptonohadi@gmail.com
}

\begin{abstract}
Language skill which lacks of attention is writing skill. It can be seen from the following evidence, the committe of Karang Taruna in Candirejo Village, Ponggok Sub-District, Blitar Regency has not been skilled in writing an official letter by using the systematics and the use of Indonesian language in terms of spelling application. The difficulty of writing letters is in accordance with the rules, so that they only write the letter and they do not pay attention systematics. It proved that there are many mistakes which made by the committe of Karang Taruna in Candirejo Village, Ponggok Sub-District, Blitar Regency in writing a letter, is in the systematical error and the use of Indonesian language.
\end{abstract}

Kata Kunci: korespondensi, surat, karang taruna

\section{ABSTRAK}

Keterampilan berbahasa yang kurang mendapatkan perhatian adalah keterampilan menulis. Hal ini dapat dilihat dari bukti berikut, Pengurus Karang Taruna Desa Candirejo Kecamatan Ponggok Kabupaten Blitar belum terampil menulis surat resmi dengan menggunakan sistematika dan penggunaan bahasa Indonesia dalam hal penerapan ejaan. Kesulitan menulis surat sesuai dengan kaidah sehingga hanya asal jadi surat dan belum memeperhatikan sistematika. Hal ini terbukti masih banyak kesalahan yang dibuat oleh pengurus Karang Taruna Desa Candirejo Kecamatan Ponggok Kabupaten Blitar dalam menulis surat, yakni kesalahan sitematika dan penggunaan bahasa Indonesia.

Kata Kunci: korespondensi, surat, karang taruna

\section{PENDAHULUAN}

Kegiatan bahasa Indonesia di sekolah secara formal dapat diperoleh mulai prasekolah sampai dengan perguruan tinggi. Bahasa Indonesia sebagai bahasa nasional mempunyai fungsi sebagai pemersatu bangsa dan sebagai pelestari serta pengembang budaya bangsa, dan bahasa Negara dalam arti sebagai bahasa resmi kenegaraan dan pengantar dalam dunia pendidikan. Kegiatan bahasa Indonesia selain memberi pengetahuan juga memberikan keterampilan baik menyimak, berbicara, membaca ataupun menulis

Salah satu keterampilan berbahasa yang kurang mendapatkan perhatian adalah keterampilan menulis. Hal ini dapat dilihat dari bukti berikut, Pengurus Karang Taruna Desa Candirejo Kecamatan Ponggok Kabupaten Blitar belum terampil menulis surat dengan menggunakan sistematika dan penggunaan bahasa Indonesia dalam hal 
penerapan ejaan, kosa kata dan kalimat.Hal tersebut dikarenakan Pengurus Karang Taruna Desa Candirejo Kecamatan Ponggok Kabupaten Blitar tidak mau belajar dan membaca buku korespodensi tentang surat menyurat. Pengurus Karang Taruna Desa Candirejo Kecamatan Ponggok Kabupaten Blitar hanya memprioritaskan prinsip asal jadi.

Menulis merupakan aktivitas yang sangat sulit dan sangat kompleks. Kesulitan aktivitas menulis karena kegiatan yang ekspresif dan produktif. Selain itu, kegiatan menulis tidak datang secara otomatis, melainkan melalui latihan dan praktik yang banyak dan teratur .

Bukti dan alasan seperti itu yang mendasari dipilihnya judul pengabdian Pelatihan Korespondensi Untuk Meningkatkan Keterampilan Menulis Surat Pada Pengurus Karang Taruna Desa Candirejo Kecamatan Ponggok Kabupaten Blitar. Hal ini dimaksudkan untuk mendeskripsikan kesalahan sistematika dan penggunaan bahasa Indonesia dalam surat menyurat.

Penyelenggaraan bimbingan teknis bagi Pengurus Karang Taruna Desa Candirejo Kecamatan Ponggok Kabupaten Blitar untuk mengembangkan keterampilan menyusun surat menyurat dan menulis proposal menjadi penting dilakukan.Terlebih masih banyak pengurus yang ternyata belum mampu menyusun surat menyurat dengan baik. Setiap hari selalu terjadi kebiasaan copy-paste surat kemarin bahkan yang lebih buruk budaya asal jadi. Hal inilah yang menjadi permasalahan -permasalahan yang perlu dikaji untuk dicarikan solusi.

Setelah melakukan pertemuan dan rapat koordinasi dengan mitra disepakati bahwa Pengurus Karang Taruna Desa Candirejo Kecamatan Ponggok Kabupaten Blitar belum menerapkan sistematika penulisan surat dengan baik menjadi masalah prioritas yang harus segera diselesaikan selama proses bimbingan teknis.

Fakta masih banyak Pengurus Karang Taruna Desa Candirejo Kecamatan Ponggok Kabupaten Blitar yang kurang membaca mengenai buku-buku tentang surat menyurat/ korespodensi. Hal tersebut menyebabkan Pengurus Karang Taruna Desa Candirejo Kecamatan Ponggok Kabupaten Blitar yang bersangkutan masih belum dapat memahami kegiatan tulis menulis dengan baik. Padahal ilmu korespodensi atau surat menyurat menjadi salah satu syarat agar pengurus bisa menulis dengan baik. Sedangkan pihak dinas terkait belum mengadakan kegiatan pembinaan kepada pengurus dalam hal tersebut. Oleh karena itu diperlukan suatu solusi berupa bimbingan teknis dalam menyusun kegiatan surat menyurat. Dalam bimbingan teknis ini akan dibagi kedalam tiga kegiatan. Kegiatan pertama yaitu bimbingan tentang korespodensi, Kegiatan kedua pendampingan dan Kegiatan ketiga seminar hasil.

Surat pada hakikatnya merupakan sebuah lembaran kertas yang digunakan sebagai sarana komunikasi tulis, baik pribadi maupun instansi yang ditujukan kepada pihak lain. Hal ini sesuai dengan pendapat Bratawidjaja bahwa surat adalah lembaran kertas yang ditulis atas nama pribadi penulis, atau atas nama kedudukan dalam organisasi yang ditujukan kepada alamat tertentu yang memuat informasi (dalam Rahardi, 2008 :11).

Selain sebagai informasi tertulis, surat juga mempunyai fungsi yang sangat luas yakni sebagai rekaman berita tentang suatu aktivitas dan sebagai bukti tertulis. Sebagaimana diungkapkan Sotyaningrum (2008:3), "Surat sebagai bukti tertulis artinya surat dapat dipergunakan sebagai bukti apabila terjadi perselisihan antara organisasi atau pejabat yang mengadakan hubungan korespondensi “. Hal itu tidak jauh berbeda dengan pendapat Finoza (2000 : 5), "Surat merupakan bukti tertulis yang dapat dijadikan arsip yang manfaatnya sebagai dokumentasi historis yang tidak perlu 
diragukan lagi ". Sebagai dokumen historis maksudnya surat dapat digunakan untuk mengetahui sejarah atau perkembangan suatu organisasi.

Berdasarkan uraian dan pendapat tersebut dapat diperoleh informasi bahwa surat merupakan alat komunikasi tulis yang mempunyai fungsi sangat penting sebagai bukti tertuli. Selain itu surat digolongkan atas beberapa jenis yakni surat pribadi, surat niaga dan surat dinas atau resmi, namun dalam PPM ini hanya difokuskan pada surat dinas.

Surat tersusun dari bagian-bagian yang setiap bagian memiliki fungsi dan cara penulisan sendiri-sendiri. Sedangkan cara meletakkan bagian- bagian surat tersebut tergantung pada bentuk surat yang dipilih. Umumnya surat bentuk surat yang dipakai adalah format setengah lurus. Beberapa bagian surat menurut pendapat Finoza (2000:75), antara lain (1) kepala surat, (2) tanggal surat, (3) nomor surat, (4) lampiran surat, (5) hal atau perihal surat, (6) alamat yang dituju, (7) salam pembuka, (8) isi surat, (9) salam penutup, (10) nama organisasi/ unit organisasi yang mengeluarkan surat, (13) nama jelas penanda tangan, (14) jabatan penanda tangan, (15) tembusan, dan (16) inisial pengonsep dan pengetik.

\section{METODE PELAKSANAAN}

Pendekatan untuk pemecahan masalah yang digunakan untuk melakukan kegiatan ini mencakup: (1) Pendidikan yang meliputi paradigma PPM korespodensi dan metode atau teknik yang digunakan dalam penulisan surat menyurat, (2) Pelatihan yang meliputi praktek penyusunan surat, (3) Partisipatori, dan (4) Penugasan. Sasaran kegiatan dalam pengabdian pada masyarakat ini adalah Pengurus Karang Taruna Desa Candirejo Kecamatan Ponggok Kabupaten Blitar yang mempunyai kemauan/minat besar dalam mengembangkan profesionalisme pekerjaan serta dalam masa pengabdian ke masyarakat.

Adapun tahapan melakukan kegiatan pengabdian pada masyarakat ini mencakup tiga kegiatan: (1) melakukan bimbingan terkait sistematika surat menyurat. Dalam kegiatan pertama ini, faktor-faktor pendukung pelaksanaan bimbingan telah disiapkan, (2) penugasan dan pendampingan, (3) melakukan seminar hasil PPM.

Mitra berkolaborasi dengan tim pengusul dalam mendukung penyeleng-garaan bimbingan teknis ini. Mitra bertugas dalam melakukan koordinasi, promosi, dan pendataan terhadap peserta yang akan mengikuti bimbingan. Mitra juga menjamin kesediaan peserta untuk mengikuti bimbingan.

Jenis evaluasi yang digunakan dalam program pengabdian kepada masyarakat ini adalah menggunakan bentuk: (1) Pre-test, yaitu persepsi sekretaris desa tentang korespodensi, (2) Post-test, yaitu mengevaluasi sekretaris desa tentang materi. Setelah bimbingan teknis berakhir dilakukan fasilitasi kepada sekretaris desa untuk menerapkan kegiatan pendampingan surat menyurat yang telah dilaksanakan dan mempublikasikan artikel hasil PPMnya di Jurnal Ilmiah.

\section{HASIL DAN PEMBAHASAN}

Kegiatan PPM yang dilaksanakan dengan acara tatap muka dan praktek penulisan surat berjalan dengan baik dan lancar. Pertemuan tatap muka dengan metode ceramah dan demonstrasi, dilanjutkan latihan/praktek untuk membuat surat, mulai dari pemilihan materi atau tujuan surat, penyusunan, pemilihan huruf, dan tampilan. Kegiatan ini dilaksanakan sehari yaitu pada Sabtu, 20 Januari 2018 pukul 13.30-16.30 WIB. Peserta kegiatan berjumlah 9 orang pengurus Karang Taruna Desa Candirejo Kecamatan Ponggok Kabupaten Blitar dan lokasi penyelenggaraan pelatihan di Ruang Karang Taruna Desa Candirejo Kecematan Ponggok Kabupaten Blitar. 
Pelaksanan kegiatan PPM ini dilakukan oleh 3 (tiga) orang tim pengabdi dengan pokok bahasan yang disampaikan mengenai:

1) Pengantar korespondensi;

2) Teori penulisan surat;

3) Langkah-langkah penyusunan surat;

4) Latihan pembuatan surat untuk berbagai kepentingan;

5) Evaluasi hasil menulis surat yang telah disusun.

Keterbatasan waktu pertemuan mengakibatkan tidak semua materi dapat disampaikan dengan detil. Kegiatan yang diawali dengan ceramah dan demonstrasi ini kemudian dilanjutkan latihan. Dari kegiatan latihan tampak bahwa mitra memang belum menguasai cara menulis surat yang baik, khususnya terkait penggunaan bahasa baku bahasa Indonesia. Acara kemudian dilanjutkan sesi tanya jawab.

Berbagai pertanyaan diajukan secara antusias oleh para peserta dalam sesi tanya jawab. Secara garis besar inti dari pertanyaan para peserta adalah:

1) Penggunaan bahasa pada penyusunan surat yang baik

2) Penggantian layout dan font dalam penyusunan surat

3) Pengaturan tampilan pada surat yang menarik

4) Analisis kesalahan surat yang telah dilakukan

Program pengabdian pada masyarakat berupa pelatihan menulis surat bagi pengurus Karang Taruna Desa Candirejo Kecematan Ponggok Kabupaten Blitar yang sudah dilaksanakan ini diharapkan dapat menambah pengetahuan, keterampilan dan lebih percaya diri dalam menyusun surat. Mitra akan lebih semangat dan termotivasi untuk mengembangkan diri. Hasil pelatihan ini akan bermanfaat bagi organisasi, khususnya dalam hal surat-menyurat dengan memperhatikan kesalahan penggunaan bahasa. Disamping itu dengan adanya pelatihan menulis surat ini akan menambah keterampilan pengurus dalam menyiapkan surat untuk kepentingan tertentu sehingga akan mendukung kemampuan pengurus dalam menyiapkan suatu kegiatan yang akan diajukan.

Hasil kegiatan PPM secara garis besar mencakup beberapa komponen sebagai berikut:

1) Keberhasilan target jumlah peserta pelatihan;

2) Ketercapaian tujuan pelatihan

3) Ketercapaian target materi yang telah direncanakan

4) Kemampuan peserta dalam penguasaan materi

Target peserta pelatihan seperti direncanakan sebelumnya adalah paling tidak 14 pengurus Karang Taruna Desa Candirejo Kecamatan Ponggok Kabupaten Blitar, sesuai dengan jumlah pengurus yang ada. Dalam pelaksanaannya, kegiatan ini diikuti oleh 9 orang peserta. Dengan demikian dapat dikatakan bahwa target peserta tercapai $80 \%$. Angka tersebut menunjukkan bahwa kegiatan PPM dilihat dari jumlah peserta yang mengikuti dapat dikatakan berhasil/ sukses.

Ketercapaian tujuan pendampingan pengembangan media pembelajaran secara umum sudah baik, namun keterbatasan waktu yang disediakan mengakibatkan tidak semua materi tentang penulisan surat dapat disampaikan secara detil. Namun dilihat dari hasil latihan para peserta yaitu kualitas penggunaan bahasa baku yang telah dihasilkan, maka dapat disimpulkan bahwa tujuan kegiatan ini dapat tercapai.

Ketercapaian target materi pada kegiatan PPM ini cukup baik, karena materi pendampingan telah dapat disampaikan secara keseluruhan. Materi pendampingan yang telah disampaikan meliputi: (1) penggunaan bahasa pada penyusunan surat yang baik; (2) penggantian layout dan font dalam penyusunan surat; (3) engaturan tampilan pada 
surat yang menarik; (4) analisis kesalahan surat yang telah dilakukan Kemampuan peserta dilihat dari penguasaan materi masih kurang dikarenakan waktu yang singkat dalam penyampaian materi dan kemampuan para peserta yang berbeda-beda. Hal ini disebabkan jumlah materi yang banyak hanya disampaikan dalam waktu sehari sehingga tidak cukup waktu bagi para peserta untuk memahami dan mempraktekkan secara lengkap semua materi yang diberikan.

Secara keseluruhan kegiatan pelatihan menulis surat untuk mengedukasi tentang penggunaan bahasa baku bahasa Indonesia yang baik dan benar dapat dikatakan berhasil. Keberhasilan ini selain diukur dari keempat komponen di atas, juga dapat dilihat dari kepuasan peserta setelah mengikuti kegiatan. Manfaat yang diperoleh guru adalah dapat menyusun surat dengan kualitas yang lebih baik dan diharapkan kualitas tersebut sudah mengikuti standar untuk dapat dipakai sebagai administrasi suatu organisasi.

\section{SIMPULAN}

Program pendampingan dapat diselenggarakan dengan baik dan berjalan dengan lancar sesuai dengan rencana kegiatan yang telah disusun meskipun belum semua peserta pendampingan menguasai dengan baik materi yang disampaikan. Kegiatan ini mendapat sambutan sangat baik terbukti dengan keaktifan peserta mengikuti pendampingan dengan tidak meninggalkan tempat sebelum waktu pelatihan berakhir.

\section{DAFTAR RUJUKAN}

Finoza, L. (2000). Aneka Surat Sekretaris dan Bisnis. Jakarta: PT Gramedia.

Jakaria, Iskandar, dkk. (2005). Aneka Konsep Surat untuk Berbagai Keperluan. Bandung: CD Pustaka Setia.

Kokasih, E. (2003). Ketatabahasaan dan Kesusastraan Bahasa Indonesia. Bandung:Yrama Widya.

Rahardi, K. (2008). Aturan Pembuatan dan Pemakaian Bahasa Surat Dinas. Yogyakarta : Pustaka Book Publisher.

Soedjito, D \& Solchan, TW. (2004). Surat Menyurat Resmi Bahasa Indonesia. Bandung: Remaja Rusda Karya.

Sotyaningrum, A.T. (2008). Korespondensi Bahasa Indonesia Dasar, Teori dan Aplikasi. Yogyakarta: Amran Book. 